\title{
(DIS)ABLING BODY AND CONSCIOUSNESS: TECHNOLOGICAL AFTERNESS AND AFTER-HUMANS IN REALIVE AND UPGRADE
}

\author{
(DES)ABILITANDO CORPO E CONSCIÊNCIA: \\ POSTERIDADE TECNOLÓGICA E APÓS-HUMANOS \\ EM REALIVEE UPGRADE
}

Asijit Datta*

\begin{abstract}
My paper talks about post-human spaces and technological afterness associated with the physiognomy of humans. Mechanical alteration in biological mechanisms is directly experienced in seizing of organic consciousness. The rupture in consciousness splits it into two distinct parts - one belonging to the disappearing human, the other to the emerging cybernetic. The new being is not another human, but (an)other human, an evolved different sameness. In the film Realive (2016) we encounter an extension of the self beyond death by re-placing it into another body. However, this enhancement diffuses all 'natural' responses and meaning-making vehicles, primarily the cognizance of death and mortality. In a classic Frankensteinian restoration, Marc is reanimated in 2084 through extensive methods of cryonization under the banner 'Lazarus project'. The post-human 'humachines' dissolve the position of the teleological man and stretch DNA to digitality. Upgrade (2018) shows us the metamorphosis of Grey Trace, a luddite, by an installed biomechanical enhancer chip, Stem. The roach-like implant not only erases Grey's quadriplegic body, but ironically 'desires' to possess and manoeuver the host's body. Robotic consciousness in these assimilated afterhumans is borrowed consciousness activated by infusing the evanescent biological particle - life. Nanotechnology, molecular machines, nerve manipulators, cameras implanted inside the brain, self-generating nanobots, artificial mechanical limbs have emerged as elements of posthuman utopia/dystopia. Paradoxically, in both the films the protagonists, after their reanimation and upgradation, try to return to their original position of death and disability. In their quest to retrieve the lived body they lose their embodied reciprocations with animals, machines and other forms of life. The mysterious, irreducible, unknown and unknowable potentiality of life is levelled and dissipated by surplus information. This paper attempts to discuss the reactions of embodied body as memory post-cryonization, and to understand limits of psychological disability and death of consciousness after technological reconstruction of the disabled body.
\end{abstract}

Keywords: posthuman; body; death.

\section{RESUMO}

Este artigo fala sobre espaços pós-humanos e pós-vida tecnológica associados à fisionomia dos humanos. A alteração mecânica no funcionamento biológico é experimentada

\footnotetext{
* The Heritage College, Mundapara, Kolkata, West Bengal, Índia. asijitdatta@gmail.com, https://orcid.org/0000-0002-9340-3727
} 
diretamente na apreensão da consciência orgânica. A ruptura na consciência divide-a em duas partes distintas - uma pertencente ao humano em desaparecimento, a outra ao cibernético emergente. O novo ser não é mais um humano, mas (um) outro humano, uma similitude diversa evoluída. No filme Realive (2016), encontramos uma extensão de um self além da morte, quando colocado em outro corpo. Porém, esse aprimoramento torna difusas todas as reações "naturais" e veículos de significado, principalmente o conhecimento da morte e da mortalidade. Em uma restauração Frankensteiniana clássica, Marc é reanimado, em 2084, por métodos de criogenização, sob a bandeira do "Projeto Lázaro". As "humáquinas" póshumanas dissolvem a posição do humano teleológico, estendendo o DNA à digitalidade. Upgrade (2018) mostra a metamorfose de Gray Trace, um ludita, via um chip intensificador biomecânico nele instalado, Stem. O implante, semelhante a uma barata, não apenas apaga o corpo tetraplégico de Grey, mas, ironicamente, "deseja" possuir e manobrar o corpo do seu hospedeiro. A consciência robótica nesses depois-de-humanos assimilados é uma consciência emprestada, ativada pela infusão da partícula biológica evanescente - a vida. Nanotecnologia, máquinas moleculares, manipuladores de nervos, câmeras implantadas no cérebro, nanorrobôs autogeradores e membros artificiais surgem como elementos da utopia/distopia pós-humana. Paradoxalmente, em ambos os filmes, os protagonistas, após sua reanimação e upgrade, tentam retornar às suas posições originais de morte e deficiência física. Buscando recuperar o corpo vivido, eles perdem sua reciprocidade corporificada com animais, máquinas e outras formas de vida. A potencialidade misteriosa, irredutível, desconhecida e incognoscível da vida é nivelada e dissipada pelo excedente informacional. Este artigo tenta discutir as reações do corpo físico enquanto memória pós-criogenização e compreender os limites da incapacitação psicológica e da morte da consciência após a reconstrução tecnológica do corpo deficiente.

Palavras-chave: pós-humano; corpo; morte.

\section{INTRODUCTION}

Body in the cybernetic age is seldom detached from its posthuman imaginings which expand the contours of the organic. The cloned, the cyborg, the android, the quasi corporeal bodies are gradually populating the upper layers of existence. However, the body that emerges out of technological synthesis is the grotesque body of the other, the reimagined half-human. A visual and psychological horror emanates from the metamorphosed otherness of such bodies. Resistance of these assemblages against all forms of corporeal totality reinstates the Frankensteinian myth of aberrant, transformative bodies. On the other hand, through these temporary bodies we indirectly encounter our own mythic overreaching in the form of hybrid interspecies, varying from centaur, sphinx and siren to hydra, cyclops and griffin. From the folklore traditions of animal fables down to Hughes's (SAGAR, 1994 , p. 23) understanding of ontology through animality, human identity has always had to travel through a post (beyond)-human lens. Paul Sheehan (2015), while analysing the science fictions of Lovecraft and Burroughs, introduces the 
inherent tendency of Homo sapiens (what Burroughs calls the 'algebra of need') to transmogrify the given body into bizarre shapes and sizes (SHEEHAN, 2015, p. 250). Symbiotic interrelations, anomalous transmutations, genetic alterations present the body as a repository of prehistoric memories; moreover, the body is corrupted by its embedded knowledge of accidental birth out of the interplay of viruses and its defective notions of selfhood due to the possession of language. Subjectivity and illusion of self are generated from the symbolic force of language, and the language 'virus' in turn castrates authentic self-expression. Therefore, the interrogator engages with the problematic equation between language and body and mystery of embodied consciousness.

Cybernetic posthumanism desires to overwrite the unstable and volatile heterogeneities of the mythic body with a renewed, balanced and durable body (SHEEHAN, 2015, p. 251), even though overloading the body with gigantic data and turning it into an enormous order receiving system has its own obstructions, and consequently this activates atavistic proclivities. Hayles theorizes the cybernetic as a wired zone that interweaves "will, desire, and perception into a distributed cognitive system in which represented bodies are joined with enacted bodies through mutating and flexible machine interfaces" (HAYLES, 1999, p. xiv). Similarly, in SF films, the post-anthropocentric subjectivity is a speculative, hybrid patchwork of the posthuman imaginary. This digital material with a defective sense of identity is primarily an outcome of technophilic fantasy. In order to establish a sort of identification with the cyborged human, the films usually employ point-ofview shots, as well as mirror and body reparation scenes (SMELIK, 2017, p. 111). Therefore, the SF films, involving the artificial human, are founded on the critical gradations of identity crisis.

Synthetic posthumanism detects a shift from postbiological to transbiological, from prosthesis to augmented machinic manifestation. Borrowing from Indian religious traditions, I would like to call this tendency towards immortality, cybernetic incarnation. Oliver Krüger traces the collapse and the end of human, and the creation of the post-human/post-sentient being from the psychedelic works of Fereidoun M. Esfandiary and Timothy Leary, the research on cryonics by Robert Ettinger in the 1970s, to the scientifico-theological foresights of Frank Tipler, computational transhumanism of Marvin Minsky, and Hans Moravec's daring proclamation of transmigration (KRÜGER, 2018, p. 48-49). It is interesting to note that Tipler's (1995) end-point Omega in The Physics of Immortality: Modern Cosmology, God and the Resurrection of the Dead, is a stage, when the sun explodes, humans dissolve into air and earth, and then exist only as computerized variations. Ironically, through this 
convergence with God science envisions a meta-punishment (a self-referential Christian damnation), akin to Judgement Day, for overestimating its own limits. Renouncing Tipler's deific downloading and continuation of self, Minsky associates himself with transhumanist aspirations related to cryonization. Consequently, Moravec delivers the last blow to conditionality and contingency of human bodies by speculating the transference of information from the "human neural architecture" (KRÜGER, 2018, p. 50) to the computer brain awaiting activation and animation; the eyes of the spasmodic body approaching death shut momentarily only to reopen inside the sockets of a metallic container.

Virtual existence inside higher geometrical and multithreaded environment, after the negation of the body, takes us to Gnostic abandonment of the prison-body in the works Erik Davis (who coins the term "techgnosis") (KRÜGER, 2018, p. 51). A horrible creation is not simply a distortion of the organized or normalized it is something which is outside both life and its finitude and exceeds the limits of death. This unbearable intimacy, that humans (environmental bodies, as I would like to call them), are anticipated to share in the future, is itself a quantum leap towards erasure of the originary body, and suspension of mind-body dualism. Posthumanist utopia promises deathless bodies and access to the restricted avenues of imagined desire and unlimited sexuality without disease. Narrow physical cavities and neural interstices of humans must give way to the open spaces and gulfs of electronics to store and process inexhaustible information.

\section{DISABLED CONSCIOUSNESS AND THE FROZEN BODY}

In Mateo Gil's Realive (2016), we experience the philosophical extremities of a limitless body through methods of cryonizaton. The enhanced body here is an assembled hybrid between cyborg and human, a protracted modification that is supposed to defy time. Divided between cyborg-ness and human-ness, the reanimated body is itself the posthuman body (a combination of the dead and the undying other inside). At the expense of defending the flesh, the brain loses its adaptive mechanisms in a foreign habitat. Concepts of time, death, freedom, memories of past relations and surroundings subside and start dissipating.

In a Frankensteinian and biblical model of restructuration, Lazarus project revives Marc's body in 2084. His body comprises "20 percent remains of vital organs and tissues" extracted from the old body, predominantly "the brain and the central nervous system", "65 percent cloned bones, muscle, nerve endings, and other organ remains, 10 percent bionic implants... and 5 percent internal technology designed 
to regulate and monitor...the functioning of the organism" (GIL, 2016, p. 26). Initially the reanimated body suffers from "thrombosis, numbness...involuntary movements, loss of equilibrium, scaling of the skin, irritation of conjunctive tissue, respiratory insufficiency, cardiac insufficiency, incontinence, impotence" (GIL, 2016, p. 39-40), and can only be restored to normalcy by the "detachable umbilical cord", his "new mechanical mother" (GIL, 2016, p. 27).

However, the greatest technological trick is the MW or the Mind Writer, a recorder of memories, also capable of extracting images and sounds and even creating art. Nothing in the body is left to the will and control of the organism, the machine arrests even the mind. Furthermore, Marc is pushed to the brink of life and suicide in the end when he discovers the macabre experimentations on dead people in the Lazarus laboratory. Animated and reanimated dead people with grotesque expressions of shock on their faces convulse in pain and die again. Their mouths spout blood and medicinal fluids, their bodies tremble, and their heads split open against walls. Biomedical sciences usurp the bypothetical body and redefine knowledge of pain, a feeling which is beyond the experiences of a body neither entirely alive nor dead. This newly acquired knowledge of pain that is endured by the quasi-living bodies belongs exclusively to the domain of the experimenter. Pain, thus, ceases to be linked with bodily suffering, and changes into an objective aftermath of another failed experiment.

Robert Pepperell (2003) refers to "neurosuspension" (or the process of brain freezing) conducted by foundations like Alcor for $\$ 50,000$ for future continuity of the same self in an alien body (or one germinated from the donor's DNA) (PEPPERELL, 2003 , p. 16). Narrowing the self to a synthesis of cerebral tissues and neural integration ruptures the holistic physical autonomy of the being developed through gland and organ responses and experiences with the immediate surroundings. Pepperell refers to this practice of dissociating the brain and assigning computational precedence to it by "rational, humanist science" (PEPPERELL, 2003, p. 24) for the evolution of the anthropoid machine's "linear model of thought" (PEPPERELL, 2003, p. 24). The post-human "humachines" (PEPPERELL, 2003, p. 123) dissolve the position of the teleological man and stretch DNA to digitality. The multiple possibilities embedded within the cryonized bodies of speculative fiction or the models of cognitive scientists to adapt to the future would either surpass the succeeding generations or end up as technological lack amidst the prospective technological surplus. Going back to Mateo Gil's Realive (2016), the prosthetic, colonized, advanced body of Marc is perpetually tyrannized by the force of past consciousness. Identity crisis surfaces from the memories of the original, immersed self, and the new body 
implanted in a laboratory setting. Marc is fractionated between defunct emotions, obsolete identity and transferable memories.

\section{DISABLED BODY AND CYBERNETIC COLONIZATION}

Leigh Whannell's classic sci-fi Upgrade (2018) introduces us to Grey Trace, a luddite and car mechanic who is eventually paralysed and ameliorated by a computer chip, Stem. In exchange for Trace's a healed quadriplegia, the metallic scrounger dives into the host's body and systematically gains total physical sovereignty over it. Grey's android body is a direct outcome of exptropian theories of bodily improvement and battle against entropy. Contrary to Whannell's position, Haraway recognizes the (re)engineered body as a movement towards embodied existence. Haraway asserts that the "machine is not at it to be animated, worshipped, and dominated. The machine is us, our processes, an aspect of our embodiment" (HARAWAY, 1991, p. 81) Conversion and prostheseis, according to them, have always been integral to the cultural and biological alterations of the human mind and body. In Whannell's antithetical version of technology biocybernetic consciousness in the newly assimilated Grey is an upgraded version of human intelligence, one that can "drive anything, talk to anything, calculate anything. It's a new, better brain" (WHANNELL, 2018, p. 8-41). Grey's after-humanness, including the robotic manoeuvrings of his limbs, is a neural phenomenon initiated by the body-snatching Stem.

The catastrophe immanent in cybernetic posthumanism is in conceiving the machine as an exclusive identity separate/d from its makers. Belonging to the pulpy genre of body horror, Whannell's work presents a liminal entity/identity that moves from bodily disfiguration to reconfiguration, physical ambiguation to pluralization, and demonstrates the human subject as an unstable category. Not only there is a proliferation of beings with biomechatronic body parts and the production of identical individuals through cloning, but we are reaching the limits of sexuality and temporality as experience by the biologically embodied human being. The magical dream of technocracy and technomancy is to exuviate the diseased body, manufacture a cybernetic brain and exist in sublime simulated reality. Disembodiment does not merely entail a rejection of the biological body; it is rather attained by defamiliarizing the known body, by remodelling, customizing, and amplifying physical and intellectual abilities and movement- related apparatuses. However, the supplanting of an exhaustible body by a motorized one simply turns the weight of contingent disability into weaponized vulnerability. Either the 
animated humanoid, or scientists of bionic integrations of electronic devices and organism, would finally take us to the ultimate, singular overtaking of the machines. The new transmuted humanity would be bioengineered, genetically expanded, and outside the unconditional, corporeal contours of the body.

Technomanic posthumanism affects us with a vision of life after life, a future of fossils without flesh and bone the archaeologists to unearth the remains. Realive seeks to negate the givenness of time incorporated in mortality and disease (cancer, in Marc's case) with the help of cryonics and futuristic rebirth. On the other hand, Grey in Upgrade repairs his disability and elevates his strength and movements by borrowing computerized consciousness. For Marc, the post-death body resembles a zombiesque parodying of life- a zombie-like figure with excess life and excess death. Parallely, Stem invades Grey's biological shell not only to become human, but to kill its creator, Eron Keen, "because I can build another Stem" (WHANNELL, 2018, p.1). Ironically, Marc and Grey end up demanding death and impairment, a recurrence of the past conditions of being rooted in life. Surplus life and technological otherness amputates them from interdependent associations with incoherent elements of life.

\section{UNDERSTANDING CORPSES AND HUMAN MOTION}

In the field of cryobiological preservation, Brian Wowk (2004) refers to the term "Medical Time Travel". Travelling through timelines of posterity, or trespassing the mortal frontiers of time, not only destroys its historicity, but makes it as illusory as geographical limits in space. Cryonics, then, is an extension of the medicinal philosophy of war on aging. In order to prevent the formation of ice particles inside the cells of bodies immersed in liquid nitrogen, and to make future devitrification possible, cryoprotectants are added; "Cryoprotectants, such as glycerol, are small molecules that freely penetrate inside cells and limit the percentage of water that converts into ice during cooling. This allows cells to survive freezing by remaining in isolated pockets of unfrozen solution between ice crystals" (WOWK, 2004, p. 138). Therefore, the process morphological vitrification is aimed at resuscitation of clinically dead humans.

Ironically, to evade the scrutiny and criticism from both the legal and the moral-theological paradigms, one such institution known as Cryonics Institute is "licensed as cemetery. It advertises that professional morticians deliver its services" (WOWK, 2004, p. 141). However, the over-progressive claim the cryonicists have been making regards the definition of death. Death, in the transhumanistic 
post-aging era, does not begin with the cessation of life: "...you are only dead when biochemistry is so badly damaged that no technology, not even molecular nanotechnology...could restore normal biochemistry with your memories intact" (WOWK, 2004, p. 142). Inevitably then, we arrive at the fundamental questions regarding the character and composition of life. Can an assemblage of past memories reconstitute lives lost in bio-traditional ways? If we consider the failure of the cryonic process, will there be suffering between death and reawakening of the body?

The bodies in the cryonic chamber are both facsimiles of their previous living forms, and objects undergoing transmutation. In the words of Cathy Waldby, these frozen cadavers resemble "still life, or nature morte" where "death involved in their production has been neutralised or cancelled out, the figures nevertheless seem to partake simultaneously of living and dead states" (WALDBY, 2000, p. 139). The human body is seized between the inevitable motion of embodiment of death and the simultaneous medicalization of life and its grand attempts to exceed the temporality of death. The quest of medicine is to overwhelm life with life, to exorcise the flesh of its propensity to putrefy from within. Anatomical examination and dissection of bodies further suggest that medicine's utopian dream of defeating death emerges out of its close encounter with the recesses of a dead body. Immortality is biomedically investigated through the looking glass of death. It works under the logic that if the prime agent of death is located by the medical apparatus, then undeniably death would be conquered.

Waldby quotes Bauman (BAUMAN, 1992, p. 138) here: "Corpses are cut open, explored, scanned, tested, until the cause is found: a blood clot, a kidney failure, haemorrhage, heart arrest, lung collapse. We do not hear of people dying of mortality...they die because there was an individual cause" (WALDBY, 2000, p. 142). Waldby refers to the plasticity of the body, its mouldable nature, which encourages various mechanisms of prosthesis (WALDBY, 2000, p. 144); the aspect of alterity induced in the body turns it into an-other of itself. Removal and replacement of external and internal body parts insert a foreign element and the procedure only ends with the cadaver as an object of scientific enquiry. Transformation of the body from plasticity to motionlessness (in death) introduces yet another version of a machine, this time for medical exploration. The corpse, in biomedicine, is a work of art, an object with repressed mysteries of biological organicity.

Prostheses seek to rectify the disability of the medical body. The rectification is also a manner of mending the way the impaired body is perceived. An additional identity is supplied by the modus operandi of one's body, which Nayar highlights 
as "embattled identities" (NAYAR, 2013, p. 140). The technological implants, thus, intend to kill the monstrous in the body, erase the abnormal from the platform of the body. Bodies, in being "networked, hybrids or congeries," are always "bodies+machines" (NAYAR, 2013, p. 145), normalized inside the wires and circuits of a techno-capitalist system. Disabled bodies, on the other hand, are more inserted (in their contingent mutations and responses) within the natural environment due to their exclusion from the lines of socio-cultural networks. The technological offering to the disabled bodies is in the form of "Assistive devices" (NAYAR, 2013, p. 146), a term camouflaging the majoritarian point of view.

Pramod Nayar (2013), in his Posthumanism, breaks down the relations which constitute subjectivity. If all bodies are perpetually dependent on other objects to reach sufficient levels of ability, then all bodies from the very beginning are always "hybrid", disabled and "cyborged" bodies (NAYAR, 2013, p. 146). Human subjectivity evolves out of its "convergence and co-evolution with devices and institutionally facilitated networks" (NAYAR, 2013, p. 146). What is re-created, re-bornin Realive is a disabled consciousness and a body with high degrees of contingency. The suspicion regarding such a second awakening raises certain pertinent questions: Who is the person waking up from decades of frozen sleep? What is the ethico-moral status of an animated cadaver? What are the requisites of its personhood? How will body and consciousness negotiate the massive gap in time and the societal changes along with it? Is it possible for a body, rewired/ transplanted to another, either through cloning or cryonics, to retain the selfhood of the previous life? And finally as Nayar asks, what is a person without the "belief systems, memories, attitudes that constitute the 'personality' of the individual"? (NAYAR, 2013, p. 149).

However, I would like to stress on the fact that even if there were methods to successfully transport, reposition and relocate the memories and ideologies of an individual, it would be impossible even for adaptive creatures like the extant Homo sapiens to find themselves embodied in an environment imbued with (technological and emotional) strangeness. Consciousness expands and continues metamorphosing during one's lifetime out of continuous encounters and interactions with the environment. From the force of wind that carries both sound and infection in a particular geographical location to the speeding car that kills on the highway and the obscene plant that grows out of fallen buildings, everything affects one's consciousness. The new stimulated body is thus an effect of de-personalization and imaginary reconstitution. Cryonics, then, desires to expunge the grotesque animality of death from the body and restore the component of life to life. While 
insentient bodies floating in the cryonic fluid mirror the inert nature of artworks, genetic alterations and manipulations wish to create physically perfect bodies akin to a realistic automaton.

In Upgrade, what the metal roach, Stem, provides to the quadriplegic body of Grey are immeasurable speed and an engineered ability in the art of killing. The machinic seduction centres around assisting Grey find the murderers of his wife, Asha. Grey's fascination with his new fusion companion is also due to the automated mode of violence, the precision it grants to the body, and his addiction to the beauty of horror it generates. Stem takes permission to act independently, and this is the beginning of the biological paradox. Once consciousness is granted to the machine, human sensitivities sensibilities are overpowered and eventually terminated. By supplying disposable and indispensable speed to the body, and making the indigenous body its own enemy, Stem not only erases disability, but expropriates the humanness of Grey. Speed overrides normal pace of the body and negates the regular movements of the flesh.

Paul Virilo (2005) contemplates the onslaught of uncontrolled speed on the animal body, the territorial body and on immobile things. Along with space and time, speed consumes living, physical reality- objects, landscapes, the gazing/ grazing animals-and flashes them on to the cinematic windscreen of the automobile. Speed, in Virilo's eyes, has attained a metaphysical dimension where "movements are only simulacra" (VIRILO, 2005, p. 115), "vision... replaces life" (VIRILO, 2005, p. 116), and physical eyes collide with terrestrial space. Dromoscopy thus, for Virilo, "opposite to the stroboscopy... displays inanimate objects as if they were animated by a violent movement" (VIRILO, 2005, p. 105); dromoscopy, through the speed of the motor-engine, sanctions "the last form of anthropomorphism" to the "voyeurvoyager" (VIRILO, 2005, p. 121) or the static audience-actor/driver. Similar to the fate of the spatial, arboreal ground, the animal body is diluted by the "irrealism of speed" (VIRILO, 2005, p. 131). In a televisual display of an athlete's performance, the microscopic detailing of his movements alienates him from his own body by turning the body as an instrument to be mended. Virilo reads it in endoscopic terms where the "dromoscopic vivisection" of the flesh interrogates the sacred zones of the body (VIRILO, 2005, p. 125); the reproduction of the gymnast's performance turns "proprioception" into a "disability to be overcome by televisual technology" (VIRILO, 2005, p. 125). We mount the motor (a foreign body) and move with savage speed to sever all physical relations with our animal body (VIRILO, 2005 , p. 43). Virilo finds in this disappearance of the body behind the machine a "deanimalization of the body", a "wrapping" which supplants the body with 
speed through "technological prosthesis" (VIRILO, 2005, p. 86). The human body is now a bridge between the primitive territorial body and the machinic body to come. In the age of inestimable speed, the disabled body, with its lack/restriction of movement, is the ideal image of the overwhelmed human rendered both helpless and futile in the face of their after-human dream.

On the other hand, the paralysed body is also a reminder of the imperfections in technological overreaching, which has failed to fix everything. Therefore, the disabled organs should either be rejected and returned with new mechanical parts or they must be thrown out of the system. Virilo (1977) poetically articulates this penetration of the machine within humans: "The body is an empty house through which pass disquieting tenants" (VIRILO, 1977, p. 108). "Speed and Politics" discusses the utilization of "unable bodies" in the First World War by Germany: "the deaf will serve in heavy artillery, hunchbacks in the automobile corps" (VIRILO, 1977, p. 83). The addition of metallic parts through surgical methods in the "dromological evolutionism" witnessed the convergence of military and industrial proletarization (VIRILO, 1977, p. 84). Via a technological metempsychosis, the technological others enter the vacant bodies, or Virilo's "metabolic vehicles" (VIRILO, 1977, p. 108).

Stem, in the film, is the ontological other which, when instated inside, transforms the human into an alien. The next phase is the dissolution of all physical markers which designate the original body as corrupted. This horrible creation is a by-product of technological ramifications- humanism's extension into the spectrum of the over-humanafter the death of man. However, the dream of humanism is, in turn, achieved by divorcing the subject from its own subjectivity, by inserting another subjectivity; the dream brings the Lyotardian "unhuman ' within humanity" (GOMEL, 2014, p. 97). On alien infestation texts, Elana Gomel (2014) writes in her "Science Fiction, Alien Encounters, and the Ethics of Posthumanism" that this

transformation preserves the body but re-crafts the mind...it is simultaneously contiguous with humanity and thus speaks in a human voice; and yet it is also radically Other and thus its voice is a counterfeit, a simulacrum, an insincere and flawed imitation. Alien infestation is a discursive site where humanity confronts its alienation from itself. (GOMEL, 2014, p. 97)

Assimilation of mind and body with the roach-shaped implant obfuscates all distinctions between the self and the other. Stem speaks human language and traps the technophobic Grey with notions of care. It is a reversal of the Terminator trope used by Cameron (1991), where the metallic body needs human skin to conceal itself. In Upgrade, the machinic brain requires an entire body to arrive at corporeality. What gets exposed is the inhuman facet of technomanic posthumanism, one 
that exceeds both form and content of subjectivity, and spills into nonhuman subjectivity. Body-snatching technological grafts kill the elemental body and turn it into a simulation. Once the initial body has been penetrated, there is no return to the original uniqueness and (biological) embodiment. Stem not only annexes and appropriates the host's body and language, its greatest victory is disguise and manipulation- traits that are human, all too human. Golem insightfully writes, "What makes the aliens "superhuman" is precisely the fact that they have "powers of imitation beyond any concept of man"; in other words, the fact that they are human" (GOMEL, 2014, p. 103). Moreover, Stem quenches the primal hunger of the self for violence; body-horror and visceral violence inflated by metallic sound effects are alien fantasies deeply rooted inside the body.

\section{VANISHING OF THE HUMAN AND ADVENT OF THE EMBODIED BEING}

Grey's uncontrolled solidarity with Stem simply suggests that the symptomatic alien has always resided within the unified subject of Humanism. Therefore, the Cartesian thinking and existing subject is, in fact, two separate entities living inside one body. The dormant, unexpressed other inside the self and body belongs not to the human, but to the everlasting post-human. The human body is a textual field open both for invasion and interpretation; this positive openness is the raison d'être of the post-human human. Linear technology not only infects primitive openness, but perverts the body to suppress humanity. Stem opens up paradoxical fields-it shows the body as a host perennially ready for embodiment and parallely pollutes the same openness by seizing and sealing the body. The fusion of human consciousness with the electronic matrix indicates a desire for "<biomediated bodies" (BRAIDOTTI, 2013, p. 90) to escape the imperfections of flesh.

In her book, The Postbuman, Rosi Braidotti (2013), invokes Deleuze and Guattari's process of "becoming machines" (BRAIDOTTI, 2013, p. 91), which entails an "enfleshed and extended" (BRAIDOTTI, 2013, p. 90) becoming with the machines. This "transversal interconnection" produces an "ontologically polyvocal" (BRAIDOTTI, 2013, p. 93) subject. Hence, Braidotti dismisses the techno-fancy of transhumanism to turn human into the cybernetic body, and settles for a "non-unitary subjectivity with ethical accountability" (BRAIDOTTI, 2013, p. 93). What is to be extracted from the intentional technological radicalism in Upgrade is that "Machinic autopoiesis means that the technological is a site of post-anthropocentric becoming, or the threshold to many possible worlds" (BRAIDOTTI, 2013, p. 94). Therefore, the human body is not an extensive site for 
technological experimentations, but a relational field which multiplies and expands with bonding, interchanging and interdependence.

Both films renounce the empty image of humanism and unearth the brutal paranoia and tension latent in the efforts to sustain the progressive fantasy of humanism. Realive ends with the dead body of Marc being retrieved again by the Lazarus scientists; therefore, the body remains outside the zones of death and transience. Marc's final justification for committing suicide (by swallowing Oxycrone) is his desire "To be nothing again. To disappear" (GIL, 2016, p. 1). He decides to record all his remaining memories in the MW and leave both as an empty mind and empty body. The act of recollection is also to gather the fragments of his self through anecdotes before the body undergoes complete ruination. Placed against the archiving, retrieving, cataloguing devices, Marc's failing remembrances are transferred under suspicion; his recent doubts regarding the machine rest on its power to manipulate, re-present, convert or delete memories. The re-inhabited body of Marc with memory and consciousness of previous life inevitably suffers alienation in the new world i his coming to life and his subsequent transcendence/ limitation in an environment rushing towards its extinction have a tragicomic resonance to it.

In Upgrade too, there is an aberrant waking up. After Stem takes possession of the entire body with its robotic neuro-consciousness, Grey is thrust to a subconscious space where he awakens with full bodily autonomy and his wife, Asha, alive. The split itself shows the sacrifice of the human for the cyborged body to arrive; the human of the past evaporates and resides in the utopian territories of wish-fulfilment, while the posthuman inhabits the primordial body of its host. With a cyberjacked body and cybernetic consciousness, the name, Grey Trace, reveals the diffused trace of the embodied human now overtaken by techno-hysteria. If memories haunt the post-body of Marc in Realive, Grey is traumatized by the loss of his primeval, authentic and contingent body. They uncover the transhumanist tropes of imagining a world erected on disembodiment and autonomy. A dislocated sense of identity emerging from Marc's undead body and Grey's simulated muscles reveal them as resurrected zombies. Sheehan understands this inestimable yearning for immortality and physical prowess through the ancient tales of myths and epics. Sheehan goes on to say that,

As the flesh-and-blood ghost that haunts the late-capitalist imaginary, the zombie represents an end-point for mythological posthumanism. What all zombies reveal, in effect, is the horrific underside of this desire; indeed, they posit a kind of cure for it. The existential anxiety that, as Nick Muntean puts it, 'one could continue to live, but be nothing', not only rescinds the 
enticements of eternal life, but also acknowledges that it is more akin to eternal punishment. (SHEEHAN, 2015, p. 250-251)

Posthumanism that preaches embodiment anticipates the arrival of collective organisms. Creation of beings (and by using "beings", I am broadening the scope for inclusion of human, non-human animals, insects, bacteria, machines and other cybernetic systems etc.) has always been an act of prosthesis and coevolution with other forms of life. Cary Wolfe deeply considers this "self-referential, autopoietic closure" (WOLFE, 2010, p. xxi) which is both open (in its absorption of dislocations and arrangements in the natural world) and closed "on the level of self-referential organization" (WOLFE, 2010, p. xxiv-xxv). If all bodies are outgrowths of neurophysiological autopoietic interactions between endless disjointed organisms, then "the environment, and with it 'the body,' becomes unavoidably a virtual, multidimensional space produced and stabilized by the recursive enactions and structural couplings of autopoietic beings who share... a "consensual domain" (WOLFE, 2010, p. xxiii-xxiv). In that sense, creations, under microscopic lenses, are always horrible. The whole sensorium of visible and invisible things synthesizing and combining with each other to engender a consortium is itself an event which evokes horror of identity formation.

\section{REFERENCES}

BAUMAN, Z. (1992). Mortality, Immortality and other Life Strategies. Oxford: Blackwell.

BRAIDOTTI, R. (2013). The Posthuman. Cambridge: Polity.

CAMERON, J. (1991). Judgement Day. TriStar Pictures.

GIL, M. (2016). Realive. Arcadia Motion Pictures.

GOMEL, E. (2014). Science Fiction, Alien Encounters, and the Ethics of Postbumanism: Beyond the Golden Rule. New York: Palgrave Macmillan.

HARAWAY, D. (1991). A Cyborg Manifesto: Science, Technology, and Socialist-Feminism in the Late Twentieth Century. New York: Routledge.

HAYLES, K. (1999). How We Became Posbthuman. Chicago \& London: The University of Chicago Press. 
KRÜGER, O. (2018). The Quest for Immortality as a Technical Problem: The Idea of Cybergnosis and the Visions of Posthumanism. In: Günter, B.; Kakar, S. (eds.), Imaginations of Death and the Beyond in India and Europe. Singapore: Springer, pp. 47-58.

NAYAR, P.K. (2014). Postbumanism. Cambridge: Polity.

PEPPERELL, R. (2003). The Posthuman Condition Consciousness beyond the brain. Bristol: Intellect.

SAGAR, K. (1994). The Challenge of Ted Hughes. London: St. Martin's Press.

SHEEHAN, P. (2015), Postbuman Bodies. In: Hillman, D.; Ulrika, M. (eds.), The Cambridge Companion to the Body in Literature. New York: Cambridge University Press, pp. 245-260.

SMELIK, A. (2017). Film. In: Clarke, B.; Rossini, M. (eds.), The Cambridge Companion of Literature and the Postbuman. Cambridge: Cambridge University Press, pp. 109-120.

VIRILO, P. (2005). Negative Horizons. London: Continuum.

VIRILO, P. (1977). Speed and Politics. Trad. Marc Politzzotti. Los Angeles: Semiotext(e), 2006

WALDBY, C. (2000). The Visible Human Project: Informatic bodies and postbuman medicine. London and New York: Routledge.

WHANNELL, L. (2018). Upgrade. Blumhouse Productions.

WOLFE, C. (2010). What is Posthumanism. Minneapolis: University of Minnesota Press.

WOWK, B. (2004). Medical Time Travel. In: Fowler, D.B.; Loew, J.; Tompkins, C.S. (eds.), The Scientific Conquest of Death Essays on Infinite Lifespans. Buenos Aires: LibrosEnRed, pp. 135-150.

Recebido: 1/06/2019

Aceito: 20/07/2019

Publicado: 13/08/2019 